\title{
Intentions And Feedback From Participants In A Leadership Training Program
}

Eleanor D. White, Bowie State University, USA

Ann Hilliard, Bowie State University, USA

Barbara T. Jackson, Bowie State University, USA

\begin{abstract}
The shortage of school leaders has led several universities to offer training programs to increase the number of qualified and certified individuals prepared to assume future leadership positions in public schools, such as assistant principals and principals. The purpose of this study was to develop, deliver and evaluate a participatory leadership training program so that more qualified individuals would take positions as leaders in the public schools. Armed with data regarding the shortage of leaders being ready to assume leadership positions in schools, a proposal was written and approved for the leadership training program that was established through grant support funding for a small university on the east coast of the United States of America.
\end{abstract}

This study took place in a small suburban university with a student population of less than ten thousand students. The training university collaborated with a large county school system with which it has had partnership programs for more than 15 years. Working in collaboration with the county school system, 16 individuals were chosen in spring 2008 to participant in an educational leadership training program for 18 months. The program ended in spring 2010. The financial aspect of the leadership training program was sponsored by a federal agency.

The leadership training program met its objectives satisfactorily. The 15 program participants met the state's standards for certification as LeveI I, School Administrators (as assistant principals). This also suggests that the leadership training program adequately prepared participants to assume the roles of school leaders. However, there were areas that needed improvement based on feedback from the participants.

Keywords: Leadership Training; Leadership Shortage; Qualified Individuals; Partnership; Collaboration; Program Development; Participants

\section{INTRODUCTION}

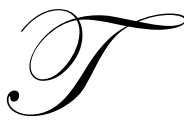

here is a shortage in the number of certified and qualified school leaders. Among the national concerns are: 1) aging of the school leadership population, 2) variations in incentives to increase the pool of school leaders, and 3) overall lack of professional development in the area of school leadership for all school personnel. States and school districts should reach out to a younger pool of promising individuals to train and become certified as school leaders. Policymakers should target their policies toward more local concerns related to education leadership (DeAngelis, Peddle \& Trott, 2002). Again, there should be more incentives available to prospective school leaders at the state, regional, and district levels. The lack of attractive incentives makes it difficult to recruit and retain school leaders. The data analysis suggests a need to closely monitor local market conditions and personnel management practices in recruiting school leaders (Baltzell \& Dentler, 1983).

More than any other group, teachers and counselors train for school leadership positions. Schools and districts need to make concerted efforts to attract high-quality individuals for potential school leadership positions. In addition, formal barriers (such as certification requirements) and informal barriers (such as district hiring practices) all but exclude people who lack teaching experience from being considered for administrative positions. 
Thus, if policymakers are serious about drawing people into administration from outside the education field, they must ensure that these barriers are reduced and a commitment to training aspiring individuals to serve in school leadership positions becomes more of a reality. Individuals from diverse backgrounds, as participants in the training, should be able to give valuable feedback from their experiences to support the validity of the training model (Gates, S. M.; Ringel, J., \& Santibanez, L., 2003).

To make a small change in the current status of the leadership shortages in schools in one community, the university instituted a leadership training program. The aim of the program was to ensure that there are qualified and certified individuals to assume leadership positions in schools. The purpose of this study was to evaluate the effectiveness of the leadership training program through the formal and informal feedback from the participants (Elmore \& Burney, 2000).

\section{PROGRAM DEVELOPMENT}

The leadership training program was developed in a collaborative manner, with input from faculty members in the Educational Leadership Department who have years of practice as school leaders. The leadership training program was adapted from a generic training systematic model. The leadership training model for the 18month program placed major emphasis on instructional modeling from experienced school leaders delivering, evaluating and assessing. When preparing the proposal for this program, faculty members and staff studied school leadership shortage information locally and across the nation. The program developers explored the most feasible way to develop, implement and evaluate the leadership training program. The process started with the trends as cited in the literature review for leadership shortages in the next decade. Second, faculty members, with the collaboration of the partnership county school system, conducted a needs assessment using participants in the traditional School Administration and Supervision Program, which helped to vision the ideal objectives specifying these questions: 1) What is to be accomplished in the leadership training program? and 2) When is it most appropriate to launch the leadership training program? The feedback from the participants in the 18-month program, who had just completed their requirements for certification, gave the faculty members information to consider for improving future programs. The leadership model for course content and experiences for future school leaders is evolving at the university, based upon the valuable results received from formal feedback provided by participants who successfully completed the program in spring 2010 (Hammond, Muffs \& Sciascia, 2001).

The educational leadership training certification program rendered instructional services to 16 teachers at a small university in the Mid-Atlantic Region of the United States. The participants selected for the leadership training program had over three years of successful teaching experience and expressed a desire to seek certification as school leaders. The training took place between fall 2008 and spring 2010 in a small suburban university with a population of less than ten thousand students. The purpose of this descriptive study was to secure feedback from the participants that could be used to improve future programs offered by the university and could be replicated at other institutions of higher learning (Anderson, 1991).

\section{OBJECTIVES, COURSES AND SIGNIFICANCE OF THE STUDY}

\section{Focused Objectives}

The School Leadership training program focused on objectives, composed by the university faculty in collaboration with the partnership county school system, were as follows:

- $\quad$ Provided participants academic course work with an emphasis on leadership development

- $\quad$ Afforded participants practice in skill development in administration and fiscal management, and also in human resources supervision, from experts currently employed in the areas of the focus

- $\quad$ Offered an opportunity for participants to engage in research and practice centered on instruction and assessment

- Exposed participants to specialized instruction and counseling on the use of technology in instruction, effective parental communication, and the law of education 
The leadership training program structure was based on three phases: 1) Preparation for Certification, 2) Orientation to School Leadership, and 3) Advanced Professional Development.

The objectives and training of the participants in the leadership program were subject to bi-monthly monitoring by faculty and staff members coordinating the program.

At the beginning of the 2008 Leadership Training Program, 16 candidates agreed to participate in all required course work and assessment activities offered by the program. At the end of the program - spring 2010 only 15 candidates actually completed their training successfully. Because of financial difficulties, one participant could not continue the program and left the program after the first semester, $\mathrm{N}=15$. Ninety-eight percent of the participants completed the course work, assessments and received their certificate of completion of the leadership training program. Professors teaching courses in the program were current education leaders, except for one professor who taught the law course. That professor was working as a school counselor, but had had prior leadership training and practice.

\section{Program Courses}

The School Leadership Training program was designed to develop competencies in educational school leadership. The leadership training program was offered to those graduate students who had both a Master's degree from an accredited institution and 27 months of satisfactory teaching performance or satisfactory performance as a specialist as defined in COMAR 13A.12.03 (Farkas, Johnson \& Foleno). The leadership training program consisted of 19 semester hours of graduate course work in administration and supervision. Courses taken by participants in the leadership training program were as follows:

- $\quad$ School Administration (3 credit hours)

- $\quad$ Supervision and Administration (3 credit hours)

- $\quad$ Curriculum Design (3 credit hours)

- $\quad$ Group Dynamics (3 credit hours)

- $\quad$ School Law (3 credit hours)

- $\quad$ Practicum/Internship (4 credit hours/2 semesters)

Code of Maryland Regulations (COMAR) requires 12 semester hours of the total required courses that must be taken for the leadership training program at the same institution, and the university limits transfer of credits into the program to a maximum of six credit hours. All courses were aligned to the Interstate School Leaders Licensure Consortium (ISLLC) Standards that were developed by the Council of Chief State School Officers in collaboration with the National Policy Board for Educational Administration (ISSLC 2008). In order to apply and be considered certified for administration one, which is at an assistant principal status, each participant completing the program had to submit their official transcript from the university to the State Department of Education for the State of Maryland with a cover letter asking for a review of the transcript course work completed and request consideration for the status of administration one.

\section{Significance of the Study}

According to Educational Research Service (2001), it has been determined that more boards and superintendents will need to hire new school leaders for their schools. It is estimated by some that $40 \%$ of the current leadership workforce will retire by 2014 (Baltzell \& Dentler, 1983); Educational Research Service, 2000; Hammond, Muffs, \& Sciascia, 2001). Many other researchers contend that such factors as physical and mental stress and the demands of the jobs will further increase their desire to retire by many current school leaders. In areas where students have a low performing record in urban and rural districts, school leaders would rather leave the profession than continue to be held accountable for students, again, who are performing far below expected standards. The turnover rate for school leaders continues to increase as the workforce grows older. According to the research, the expectations for new emerging school leaders will call for them to be more experience with diverse groups, more technological savvy, more professionally capable of delivering instructional modeling of leadership, and more flexible and mobile than leaders two decades ago (Gates, 2003). 
Armed with such data regarding the shortage of educational leaders and school personnel's lack of readiness to assume leadership positions in schools, the leadership training program was established. Through a grant awarded by a federal agency to a small suburban university educating less than ten then, the university was successful in preparing 15 candidates for state certification as school leaders from effective planning, organizing, implementing, monitoring and evaluating the leadership training program (Hollenbeck, 1994).

\section{METHODOLOGY}

Prior studies have been conducted relating to leadership training programs for prospective school leaders, but there is a deficit in the pool of information surrounding whether the training services and resources were helpful in preparing participants to become school leaders/administrators. Discovering the disparity between the beliefs and behaviors of participants might provide great insight into the contributions of future leadership training programs at smaller urban universities (Barnett, McCormick \& Conners, 1999).

This study employed a survey design utilizing primary data. Survey design provides a quantitative or numeric explanation of trends, attitudes or opinions by examining the 16-participant population. In order to accomplish this goal, surveys, questionnaires or structured interviews were conducted for data collection with the intention of generalizing a sample to the population (Creswell, 2009). This was chosen as the most effective way to collect data for this study as the perceptions of the participants were examined to determine their views as they relate to training services, resources and program strengths and weaknesses.

Sixteen teacher educators $(\mathrm{N}=16)$ from a large school district were selected to participate in the leadership training program. To receive feedback from the participants, an outside assessor with NCATE and Middle States experience conducted group and individual interviews as part of the evaluation process. There was also an online open-ended survey conducted by the assessor during the last semester of the program. A follow-up was made by program administrators to determine where the participants were in their current positions. It was learned that the majority of participants have sought after and received their Administration One certification license from Maryland State Department of Education. However, only half of the individuals in the training program have advanced to other positions because of the economy and cutbacks in leadership positions in the participating school district.

\section{Program Format and Process}

For the duration of the leadership training program, participants were provided instructional methods that included lecture and discussions, workshops, case studies, group and individual presentations and discussions, portfolios, research, role playing, internship/practicum, and the opportunity to attend regional and national conferences. Courses were held in rooms that were equipped with modern-day technology access. Participants did not live on the campus. Participants commuted weekly to their classes. Some of the participants participated in carpooling arrangements during their training experience. Much consideration was given to program quality and also for convenient access to participants.

\section{Program Evaluation}

The formal evaluation of the program was executed to identify the leadership training program's strengths and weaknesses so that improvements could be made for future programs that are similar in design. The leadership program was designed to engage participants in relevant and innovative activities for school leadership success. The overall program was formally evaluated during the last semester of training in spring 2010. Methods of individual and group interviews and an open-ended on-line survey, by an independent outside assessor from a research council organization were used to evaluate the program.

The evaluation instrument was designed by experts in the field. The outcome of the evaluation measured the overall views of the participants based on the skills and knowledge gained from the leadership training program experience and how these individuals felt about the training they received during the 18-month program. Questions asked from the survey focused on demographic information and background of the participants, how well the leadership skills were taught, satisfaction of program services, importance of the leadership courses, curriculum 
design, and specific courses taught; i.e., group dynamics, school law, curriculum design, school supervision, and practicum/internship one and two. The formal evaluation survey was distributed during the last semester of the training program. The results of the evaluation were given to the participants and a report was electronically sent to the university and the federal funding agency.

\section{DATA ANALYSIS AND RESULTS}

The evaluation results were derived from the many responses recorded by the 15 program participants. Emphasis was placed on the relevancy of courses and how well the courses were taught. The scale used in the evaluation was as follows:

- The overall satisfaction rate of how the skills were taught in the leadership training program was from $1.67 \%$ to $2.87 \%$ on a scale of 1.00 to 4.00 .

- $\quad$ The overall satisfaction of the services received during the program was $2.27 \%$ to $3.93 \%$ on a scale of 1.00 to 5.00 and the experienced professors was the major strength of the program.

- $\quad$ Satisfaction with the school administration was ranked from $3.40 \%$ to $4.47 \%$ on a scale of 1.00 to 5.00 and the statement was made that the professors used a variety of instructional methods, including technology.

- $\quad$ The curriculum design course was ranked from $2.86 \%$ to $4.43 \%$ on a scale of 1.00 to 5.00 .

- $\quad$ The group dynamics course rate was $3.31 \%$ to $4.54 \%$ on a scale of 1.00 to 5.00 .

- $\quad$ Satisfaction of the law course ranked from $2.54 \%$ to $3.54 \%$ on a scale of 1.00 to 5.00 . Participants felt that there was not enough time to cover the expectations for the course and that papers were not returned in a timely manner; plus, the law course professor was not a currently practicing school leader but rather a school counselor.

- $\quad$ The school supervision course was ranked $3.67 \%$ to $4.58 \%$ in the satisfaction manner on a scale of 1.00 to 5.00 .

- $\quad$ The field experience during the internship and practicum ranked at a satisfactory level of 3.75 to 4.50 for practicum one and $3.60 \%$ to $4.60 \%$ on a scale of 1.00 to 5.00 (Research Council, 2010).

Qualitative data showed that some participants felt improvements should be made in the following areas:

- $\quad$ More classroom discussion and less Power Point presentations

- $\quad$ Visit other districts and attend more board meetings

- $\quad$ Avoid having classes during the holidays that fall near weekends

- $\quad$ Spread the classes out over a longer period of time

- $\quad$ Assess the field experiences in a separate survey or questionnaire

- $\quad$ Place more emphasis on budget and finance

- $\quad$ Give all expectations of the program up front from day one

- $\quad$ Place heavy duty experiences in the program during the summer months

\section{Demographic Characteristics of Participants}

Fifteen of the participants completed the entire leadership training program. The ages of the participants ranged between $25-34$ at $40 \%, 35-44$ at $33 \%$, and $45-55$ at $27 \%$. In summary, the ages of the participants were between 25 and 55. The race of participants was black 67\% and Caucasian 33\%. Two thirds of the participants identified themselves as Black while the others identified themselves as Caucasian. The gender was male at $7 \%$ and female at $93 \%$. All but one of the fourteen of the participants was female (Research Council, 2010).

\section{Program Participants' Professional Involvements} below:

Other data collected about the participants were related to their professional involvement, as summarized

- $\quad$ Served as members of ASCD, TESOL, NAEYC and on school leadership teams 
- $\quad$ Served as members of Multicultural Steering Committee Title IX area designee

- $\quad$ Served as department chairpersons and mentor for student teachers

- Participated in writing curriculum, professional development coordinator, assessment team members, academic coach, and tag coordinator

- $\quad$ Served as school leader and team manager, gained status as National Board Certified Teacher and members of various Greek and Academic organizations

\section{Acquisition of Knowledge}

Participants gained more relevant knowledge after participating in the leadership training program. The participants gave an overall satisfaction rating of the program related to curriculum offering, instructional delivery services, field experiences, and exposure to leadership conferences and seminars.

\section{Level of Skills}

Participants gained skills and knowledge of confidence in handling various types of problems that could occur in a school environment. Participants felt that they improved their skills in supervising staff, getting the best from individuals in a group dynamics setting, and to value the views of others. Participants gained improved skills in decision-making in a collaborative manner. Participants felt that the technology used to support learning was very effective, such as video clips, internet research, useful websites, additional texts, educational online articles, longitudinal data, and various case studies.

\section{DISCUSSION}

Because of the shortage of leaders being trained to accept positions in schools, leadership training programs should continue at universities to expand the pool of qualified and certified individuals being ready to assume various roles of leadership in schools. In order for leadership training programs to remain effective, the coordinators of such programs must stay current regarding the needs and expectations of programs to meet the demands of school systems to improve student achievement through improved and continued relevant staff development activities for faculty and staff. When the needs assessment is conducted, it is necessary to construct specific objectives as to what to be accomplished in the training program; craft the curriculum to be current and relevant; provide interactive training with best practitioners in the broader community; make sure that there is stronger development of skills and knowledge taught for all participants in the program; embrace more effective modeling of expectations for school leaders; use current standards when planning and evaluating the program, and make sure that the curriculum in use empowers the participants in the program. The evaluation should show that the intended objectives met participants' needs and are effective for individuals seeking current leadership positions.

\section{LIMITATIONS OF THE STUDY}

The limitation of this study included only individuals who were currently serving as teachers or program coordinators. In this training program, participants were not current school leaders, such as assistant principal or principal. Participants in this study were from only one large county school district near the university. Formal evaluation of the program was conducted during the last semester instead of after nine credits had been completed. The evaluation of field experience was done on the same evaluation scale as the evaluation instrument used for classroom curricular activities.

\section{CONCLUSION}

The leadership training program has given the participants an opportunity to gain more skills, knowledge and to re-evaluate their own attitudes about wanting to go into school leadership positions. One individual stated that she would like to become a "professional development facilitator within her school" and two others stated that they would like to stay "in the classroom with the children." Ninety-five percent of the participants in the program stated that the leadership training model was effective in their opinion. 
Some participants expressed that there was too much to do in a short period of time and they offered the following suggestions: 1) avoid scheduling of classes near a holiday weekend, 2) offer written feedback in a timely manner, 3) give all expectations at the beginning of the training session during orientation, and 4) make sure that all professors teaching are currently serving in a leadership position (Research Council, 2010).

From the data given, the leadership training program model allowed for typical generic and systematic approaches in planning, organizing, implementing, monitoring and evaluating the program. The training for the participants was based on standards-driven and practical-based curriculum. The continuous monitoring and evaluating of the model was formal and informal. The frequency of evaluating the program could lead to improving the effectiveness of leadership training for participants seeking school-based leadership positions. In summary, the leadership training program met the specific objectives overall at a satisfactory level based on all data collected and analyzed, and this model could serve in an effective manner for future leadership training programs.

\section{AUTHOR INFORMATION}

Eleanor D. White, Assistant Professor in the College of Education, teaches in the Department of Educational Leadership at Bowie State University, U.S.A. The author has taught classes in Philosophical and Historical Foundations of Urban Leadership, Dissertation I and Dissertation II, Human Resource Administration, and Educational Policy. She is interested in research related to school improvement; enhancing the content knowledge and professional skills of school leaders, as well as, discovering techniques to assist doctoral candidates in the completion of their course of study and the writing of the dissertation. Education: Doctor of Education in Educational Leadership, NOVA Southeastern University; Master in Business and Public Administration, Southeastern University; Bachelor of Science in Secondary Education, District of Columbia Teacher's College; Advanced Professional Certificate, Loyola University. E-mail: ewhite1 @ bowiestate.edu

Ann Toler Hilliard, Ph.D., is an assistant professor and teaches in the Department of Educational Studies and Leadership at Bowie State University, U.S.A. The author has taught classes in human resources, educational policy, educational planning and evaluation, and group dynamics. She is interested in research related to finding ways to improve the dissertation experience for doctorate candidates, data-driven decision-making at the university, and best practices for decreasing the number of dropouts in graduate programs in colleges/universities. Dr. Hilliard has her Ed.D. from George Washington University, M.S. from Johns Hopkins University, M.A.T. from Trinity University, and B.S. from Elizabeth City State University. Email: draph1@juno.com

Barbara Talbert Jackson, Assistant Professor, teaches in the Department of Educational Studies and Leadership at Bowie State University, U.S.A. The author has taught these classes: School Administration, School and Community Relations Curriculum Change and Instructional Methods, School Seminar and Practicum. She is interested in research related to the academic achievement of males and educating gifted students. Education: Ph.D., Union Institute, Cincinnati Ohio; Certificate in School Law, Harvard University, Cambridge, Massachusetts; Certificate in The Superintendents' Academy, Ohio State University, Columbus, Ohio; M.A., Antioch University, Yellow Springs, Ohio; and B.S., District of Columbia Teachers College, Washington, DC. E-mail: bjackson@bowiestate.edu

\section{REFERENCES}

1. Anderson, M.E.(1991).Principals: How to train, recruit, select, induct and evaluate leaders for America's schools. Washington, DC: ERIC Clearinghouse on Educational Management. Retrieved February 19, 2010, from http://eric.uoregon.edu/pdf/books/principal.pdf.

2. Baltzell, D., \& Dentler, R.(1983).Selecting American school principals: A sourcebook for educators. Cambridge, MA: Abt Associates, Inc.

3. Barnett, K, McCormick, J, \& Conner, R. (1999). A study of the leadership behavior of school principals and school learning culture.

4. Creswell, J. (2008). Research Design: Qualitative, Quantitative, and Mixed Methods Approaches, University of Nebraska, Sage Publication, Inc., Los Angeles, Ca. 
5. DeAngelis, K.J., Peddle, M.T., \& Trott, C.E. (with Bergeron, L.).(2002).Teacher supply in Illinois: Evidence from the Illinois teacher study [Policy Research Report]. Edwardsville, IL: Illinois Education Research Council. Retrieved February 19, 2010, from http://ierc.siue.edu/documents/kdReport1202_Teacher_Supply.pdf.

6. Educational Research Service. (2000).The principal, keystone of a high achieving school: Attracting and keeping the leaders we need. Arlington, VA: Author.

7. Elmore, R., \& Burney, D. (2000).Leadership and learning: Principal recruitment, induction, and instructional leadership in Community School District \#2, New York City. Pittsburgh, PA: University of Pittsburgh, Learning and Research Development Center.

8. Farkas, S., Johnson, J., \& Foleno, T. (with Duffett, A., \& Foley, P.).(2001). A sense of calling: Who teaches and why. New York: Public Agenda. Retrieved February 19, 2010, from http://www.publicagenda.org/files/pdf/sense_of_calling.pdf

9. Gates, S., Ringel, J., Santibañez, L., Ross, K., \& Chung, C., (2003). Who is leading our schools? An overview of school administrators and their careers. Santa Monica, CA: RAND.

10. Hammond, J., Muffs, M., \& Sciascia, S. (2001).The leadership crisis: Is it for real? Principal, 8(2), 28-29, $31-32$.

11. Hanover Research Council, Washington, D. C., 2010.

12. Hollenbeck, G.P. (1994).CEO selection: A street-smart review. Greensboro, NC: Center for Creative Leadership.

13. Interstate School Leaders Licensure Consortium Standards, 2008. 